\title{
Impact of WTO Reforms on Trade Agreements on Cotton and Clothing in Pakistan
}

\author{
Faraz Abid Lakhani ${ }^{1}$, Anwar Ali shah G. Syed ${ }^{2}$, Naveed Shaikh ${ }^{3} \&$ Faiz. M. Shaikh ${ }^{4}$ \\ ${ }^{1}$ Institute of Business \& Technology, Karachi, Pakistan \\ ${ }^{2}$ Business Administration \& Pro-Vice Chancellor, Sindh University Campus, Dadu, Sindh, Pakistan \\ ${ }^{3}$ SALU, Khairpur, Pakistan \\ ${ }^{4}$ SZABAC, Dokri, Larkana, Pakistan \\ Correspondence: Faiz. M. Shaikh, SZABAC, Dokri, Larkana, Pakistan. E-mail: faizanmy2000@hotmail.com
}

Received: May 28, 2012 Accepted: November 6, 2012 Online Published: November 14, 2012

doi:10.5539/mas.v6n12p27 URL: http://dx.doi.org/10.5539/mas.v6n12p27

\begin{abstract}
The current research examines the WTO and its impact on of trade agreements on cotton and clothing in Pakistan Data were collected from various secondary sources and analyzed by using SPSS-18. It was revealed that the World Trade Organization (WTO). ATC set out a transitional process for the ultimate removal of quotas and the full adoption of Cotton and clothing products into GATT rules. It was signed in the Uruguay Round of negotiations by this agreement, countries Canada, the EU, Norway, and the US committed to a progressive elimination of MFA restrictions within 10 years, and since January 2005 the WTO is fully implemented. It was revealed that WTO reforms has positive impact on the cotton and cotting exports on Pakistan's economy. It was further revealed that these trade reforms also bootup the SAFTA trade.
\end{abstract}

Keywords: WTO, trade, cotton, Pakistan

\section{Introduction}

Since the industrial revolution in the 18th century, the Cotton industry is still playing very important role not only in the global domestic markets, but also in worldwide trade. This vital role can be appreciated by examining the development patterns of developed economies like the UK, USA, Japan and France. During $19^{\text {th }}$ century, GDP share of the Cotton in UK was more than 50\%. USA, France and Japan (amongst other developed economies) show similar patterns.

Today Cotton and clothing trade represent about $5.7 \%$ of world exports. Fast growing economies have major share of this sector in their total exports and GDP. Pakistan has $67 \%$ share of Cotton and clothing in its total exports. Other fast developing countries like China (18\%), India (23\%), Sri Lanka (60\%) and Turkey (33\%) show similar trends (Washington Post). Many of the developing countries highly depend on this industry because this often seems to be the only industry where investment can be made due to a number of factors discussed later.

Currently, the Cotton products and garments are the main finished commodities to export for many countries, like USA has around 3\%, Turkey $10 \%$, Pakistan 10\%, China $8 \%$, India $4 \%$ of total GDP share (Diao \& Somwaru, 2000). On the other hand Cotton and clothing industry had played the very important role to generate employment. During $18^{\text {th }}$ and $19^{\text {th }}$ centuries, this industry provided around $40 \%$ employment in the developed countries like UK, USA, and France. Similarly developing countries like Pakistan, India, China, Turkey and Sri Lanka have this industry as major source of employment. Labour employment in Cotton and clothing industry of Pakistan is $40 \%$, India 30\%, China, 25\%, Bangladesh 15\% and Turkey 20\% (Diao \& Somwaru, 2001). This way after agriculture this is the major employment creating sector in Pakistan, India and Bangladesh.

In general, the Cotton industry is a main industry of a country at the early stages of industrialization. Moreover Cotton and clothing sectors can be seen as a supply chain consisting of a number of discrete activities. Increasingly the supply chain from sourcing a raw material via design and production to distribution and marketing is being organised as an integrated production network. Further production is divided into specialised activities and each activity is located where it can contribute the most to the value of the end product (Nordas, 2004). In other words the Cotton and clothing industry guarantee the consumption of garments, enlarge the economic out put by exports 
and create opportunities for labour. The world market of Cotton and clothing has been subject to the trade regime of Multi Fibre Agreement for decades. MFA is an agreement which is in basic conflict with the core principles of WTO, such as transparency and non-discrimination. Developed countries have protected their domestic Cotton industries from the cheaper imports of developing countries. Economic "globalization" is a historical process, the result of human innovation and technological progress. It refers to the increasing integration of economies around the world, particularly through trade and financial flows. The term sometimes also refers to the movement of people (labour) and knowledge (technology) across international borders.

Wolf notes that the 1870 s experienced an obvious reaction of a long upswing of liberalism of $19^{\text {th }}$ century. This reaction reached its peak in the first half of the $20^{\text {th }}$ century. Multilateralism was replaced by bilateralism, free trade by protectionism, capital freedom by exchange controls, the gold standard by fiat money and free movement of labour by powerful restrictions. The new millennium's anti-globalisation forces lauded a new world, the socialist paradise. But the collapse of liberalism in the $20^{\text {th }}$ century resulted into war, hyperinflation, worldwide depression, mass unemployment, and tyranny. Between 1870 and 1913, global GDP per capita grew 1.3 percent, while in the years 1913-1950 it grew at just 0.9 percent. The liberal market economy had produced the fastest increase in living standards ever known. The era of collectivist (socialist) was the worst period for growth in living standards of the past 130 years (Ibid).

According to Wolf, globalisation is the only system of governance where harmonious and cooperative interstate relations are a natural outcome. The prosperity of a liberal nation derives not from the size of territory, its military power, or population under its direct control, but rather from the combination of internal economic development with international exchange.

It is a function of the growth of competition in an international free trade system which is intensified by the diffusion of technology. It is therefore a function of the increase in the density and complexity of international interactions. The intensification of these processes has a qualitative change in the pattern of constraints and opportunities facing actors, particularly states (Reich, 1998).

\section{Data Collection Methodology}

Data were collected from various secondary sources like Magazine, Annual Reports of Pakistan Cotton Board Export Promotion bearu, All Pakistan Cotton Mills Association (APTMA and various repots. Data were analyses by using Statistical software SPSS-18.

\section{Importance of Cotton Trade}

\subsection{Evolution of Cotton Agreements}

We will discuss different agreements briefly in this section.

General Agreement on Tariffs and Trade (GATT) used to play very important role in world trade sphere since it became effective in January 1948. The Articles of the GATT were originally agreed in 1947 (referred to as GATT 1947) and subsequently, with some revisions, in 1994 (referred to as GATT 1994) as part of the Uruguay Round negotiations that created the World Trade Organization (WTO). The principles of the GATT became the basic rules and regulations of international trade. The main purpose of the GATT was to promote free trade with abolition of tariffs and reduction in quota tariffs. Let's have a brief look on some important articles of the GATT 1994.

Article I of GATT 1994 contains the most favoured nation (MFN) treatment which means non discriminatory treatment among the members (Bhagirath Lal Da, 1999)--The world Trade Organisation). MFN treatment and states that trade concessions granted to one Member are applied immediately and without conditions to all other Members. Under this condition even the most-friendly member will be equally treated like others. Article II explains the Schedules of Concessions which means all trade concessions made by Members must be stated and incorporated into the legal agreement - 'bound' rates. No other Member may be treated less favourably than any 'bound' rate. Article III is about National Treatment on Internal Taxation \& Regulation. It explains that members may not use internal measures to discriminate between domestic goods and those imported from Members; that is to say that imports from Members are accorded National Treatment.

While article V is about Freedom of Transit which states that "Apart from standard customs procedures, no trade measures or other regulations to be applied by Members to goods in transit between other Members" Anti-Dumping \& Countervailing Duties are explained in article VI which explains that members may apply duties and other measures can be applied to goods originating in other Members which are dumped and/or enjoy export subsidies subject to specific conditions. Similarly article XI is about General Elimination of Quantitative Restrictions that trade restrictions should be in the form of duties, taxes and other charges whether effective 
through quotas, import and export licenses and other measures, ultimately requiring the ratification of all quantitative restrictions. All new trade measures to be in the form of tariffs.

In addition to all above use of fees \& formalities connected with importation and exportation, publication \& administration of trade regulations, governmental assistance to economic development and emergency action on imports of particular products were also included.

The GATT promotes the principles of Non-discrimination, market access and free trade. Also it requires cutting the tariffs and clearing the tariffs barriers in international trade area. But the most important service of GATT is to negotiate multilateral extensions of tariff reduction through the application of the most favoured nation clause.

The trade of Cotton products and garments is an important part of the international trade. Since 1948 to 1995, the developed countries worked out a serious trade protection system against the developing countries. Quantitative restrictions and high tariffs were used for this purpose. In spite of all positive and negative aspects, GATT provided the framework for most important international tariff negotiations from 1948 until 1994.

\subsection{The MFA and Its Fundamental Characters}

Protection against Cotton and clothing import is a frequent happening in economic history. The starting point of protection can be taken 1957, when US influenced Japan to agree on five years voluntary limit on its cotton export to US. But due to reduction of shipment of cotton Cotton from Japan increased exports of same product of Hong Kong dramatically. Likewise other developing countries accounted increase in their exports, although not as much as Hong Kong did. In order to limit the huge flow of cotton exported from developing countries, US pushed to the conclusion of multilateral agreement which led to STA (Short Term Agreement) in 1961. Basically STA was a primary shape of MFA which was imposed to protect the domestic Cotton industry of USA. This agreement imposed more restrictions on imports from the developing countries which were increased due to GATT and voluntary restrictions from Japan. This STA was converted to LTA (Long Term Agreement), which was more widespread, in the following year (1962). Nevertheless, constraint on cotton exports jointly with new improvement of technology changed the preference of consumers to manmade fibre products which were again the area of developing countries. The US again responded rapidly and pushed for new accord which put a ceiling on trade in manmade fibres in addition.

Table 1. GDP deflator of Pakistan

\begin{tabular}{lccccccc}
\hline Year & $\mathbf{1 9 8 0}$ & $\mathbf{1 9 8 1}$ & $\mathbf{1 9 8 2}$ & $\mathbf{1 9 8 3}$ & $\mathbf{1 9 8 4}$ & $\mathbf{1 9 8 5}$ & $\mathbf{1 9 8 6}$ \\
Deflator & 19.851 & 21.981 & 24.041 & 25.309 & 27.752 & 29.011 & 29.966 \\
\hline Year & $\mathbf{1 9 8 7}$ & $\mathbf{1 9 8 8}$ & $\mathbf{1 9 8 9}$ & $\mathbf{1 9 9 0}$ & $\mathbf{1 9 9 1}$ & $\mathbf{1 9 9 2}$ & $\mathbf{1 9 9 3}$ \\
Deflator & 31.32 & 34.332 & 37.234 & 39.925 & 45.086 & 49.561 & 54.137 \\
\hline Year & $\mathbf{1 9 9 4}$ & $\mathbf{1 9 9 5}$ & $\mathbf{1 9 9 6}$ & $\mathbf{1 9 9 7}$ & $\mathbf{1 9 9 8}$ & $\mathbf{1 9 9 9}$ & $\mathbf{2 0 0 0}$ \\
Deflator & 61.115 & 69.595 & 75.423 & 85.517 & 91.953 & 97.343 & 100 \\
\hline Year & $\mathbf{2 0 0 1}$ & $\mathbf{2 0 0 2}$ & $\mathbf{2 0 0 3}$ & $\mathbf{2 0 0 4}$ & $\mathbf{2 0 0 5}$ & - & - \\
Deflator & 107.891 & 110.549 & 115.456 & 124.402 & 133.143 & - & -
\end{tabular}

Source: International Monetory Fund (IMF) 2005. 
Table 2. Sectoral share in GDP and growth rate in GDP/components (Percent)

\begin{tabular}{|c|c|c|c|c|c|c|c|}
\hline \multirow[b]{2}{*}{ Years } & \multicolumn{2}{|c|}{ Agriculture } & \multicolumn{2}{|c|}{ Manufacturing } & \multicolumn{2}{|c|}{ Services } & \multirow{2}{*}{$\begin{array}{l}\text { Growth in } \\
\text { GDP }\end{array}$} \\
\hline & $\begin{array}{c}\text { Share in } \\
\text { GDP }\end{array}$ & Growth & $\begin{array}{c}\text { Share in } \\
\text { GDP }\end{array}$ & Growth & $\begin{array}{c}\text { Share in } \\
\text { GDP }\end{array}$ & Growth & \\
\hline $1950-51$ & 51.94 & 2.55 & 6.68 & 8.39 & 39.68 & 4.60 & 3.82 \\
\hline $1951-52$ & 48.48 & -8.28 & 7.32 & 7.74 & 42.00 & 4.01 & -1.73 \\
\hline $1952-53$ & 47.67 & 0.16 & 7.90 & 9.96 & 42.16 & 2.25 & 1.86 \\
\hline $1953-54$ & 49.80 & 14.93 & 8.11 & 12.98 & 39.85 & 4.00 & 10.03 \\
\hline $1954-55$ & 47.62 & -2.78 & 8.97 & 12.35 & 41.16 & 5.00 & 1.66 \\
\hline $1955-56$ & 47.08 & 2.32 & 9.53 & 10.05 & 40.95 & 2.94 & 3.49 \\
\hline $1956-57$ & 46.67 & 2.02 & 9.77 & 5.43 & 41.06 & 3.09 & 2.91 \\
\hline $1957-58$ & 46.42 & 2.07 & 9.87 & 3.74 & 40.90 & 2.33 & 2.63 \\
\hline $1958-59$ & 45.66 & 3.76 & 9.75 & 4.18 & 41.50 & 7.05 & 5.49 \\
\hline $1959-60$ & 45.61 & 0.83 & 9.91 & 2.53 & 41.47 & 0.85 & 0.93 \\
\hline $1960-61$ & 43.41 & -0.39 & 10.68 & 12.85 & 41.98 & 5.98 & 4.67 \\
\hline $1961-62$ & 43.58 & 6.04 & 11.45 & 13.28 & 41.30 & 3.89 & 5.61 \\
\hline $1962-63$ & 42.74 & 4.91 & 11.90 & 11.18 & 41.33 & 7.05 & 6.97 \\
\hline $1963-64$ & 41.61 & 3.83 & 12.43 & 11.34 & 41.21 & 6.34 & 6.65 \\
\hline $1964-65$ & 39.91 & 4.99 & 12.48 & 9.93 & 42.63 & 13.22 & 9.45 \\
\hline $1965-66$ & 37.73 & 0.86 & 12.70 & 8.58 & 44.61 & 11.67 & 6.70 \\
\hline $1966-67$ & 38.55 & 6.00 & 12.94 & 5.65 & 43.84 & 1.95 & 3.74 \\
\hline $1967-68$ & 40.27 & 11.66 & 12.87 & 6.37 & 42.44 & 3.48 & 6.90 \\
\hline $1968-69$ & 39.51 & 4.15 & 13.17 & 8.62 & 42.21 & 5.56 & 6.15 \\
\hline $1969-70$ & 39.52 & 9.12 & 13.44 & 11.32 & 41.29 & 6.72 & 9.10 \\
\hline
\end{tabular}

Source: 50 Years of Pakistan Volume I summary, Economic Survey, Various Issues.

Table 3. Sectoral share in GDP and growth rate in GDP/components (Percent)

\begin{tabular}{cccccccc}
\hline \multirow{2}{*}{ Years } & \multicolumn{2}{c}{ Agriculture } & \multicolumn{3}{c}{ Manufacturing } & \multicolumn{2}{c}{ Services } \\
\cline { 2 - 6 } & $\begin{array}{c}\text { Share in } \\
\text { GDP }\end{array}$ & Growth & $\begin{array}{c}\text { Share in } \\
\text { GDP }\end{array}$ & Growth & $\begin{array}{c}\text { Share in } \\
\text { GDP }\end{array}$ & Growth & GDP \\
\hline $1970-71$ & 35.40 & -2.79 & 17.20 & 6.44 & 43.40 & 2.31 & 1.05 \\
$1971-72$ & 35.43 & 2.77 & 17.21 & 1.26 & 43.43 & 3.33 & 2.08 \\
$1972-73$ & 35.45 & 1.70 & 17.30 & 8.73 & 43.53 & 9.52 & 6.70 \\
$1973-74$ & 35.49 & 3.83 & 17.36 & 6.35 & 43.61 & 9.05 & 7.01 \\
$1974-75$ & 35.46 & -2.52 & 17.37 & 0.54 & 43.70 & 8.29 & 3.26 \\
$1975-76$ & 35.50 & 4.47 & 17.38 & 1.39 & 43.71 & 1.79 & 3.37 \\
$1976-77$ & 35.53 & 2.98 & 17.40 & 1.82 & 43.75 & 2.71 & 2.81 \\
$1977-78$ & 35.56 & 3.50 & 17.50 & 10.21 & 43.85 & 10.31 & 7.84 \\
$1978-79$ & 35.59 & 3.41 & 17.58 & 8.01 & 43.91 & 6.18 & 5.57 \\
$1979-80$ & 35.64 & 5.89 & 17.68 & 10.25 & 43.97 & 5.87 & 6.91 \\
$1980-81$ & 30.83 & 3.93 & 15.11 & 10.63 & 44.57 & 6.31 & 6.21 \\
$1981-82$ & 30.01 & 4.72 & 15.98 & 13.75 & 44.72 & 7.90 & 7.56
\end{tabular}




\begin{tabular}{llllllll}
$1982-83$ & 29.34 & 4.40 & 16.02 & 7.03 & 47.79 & 9.24 & 6.79 \\
$1983-84$ & 26.86 & -4.82 & 16.62 & 7.89 & 49.59 & 7.90 & 3.97 \\
$1984-85$ & 27.41 & 10.92 & 16.52 & 8.09 & 49.24 & 7.92 & 8.71 \\
$1985-86$ & 27.30 & 5.95 & 16.71 & 7.55 & 48.96 & 5.77 & 6.36 \\
$1986-87$ & 26.64 & 3.25 & 16.98 & 7.53 & 48.99 & 5.86 & 5.81 \\
$1987-88$ & 25.71 & 2.73 & 17.55 & 9.98 & 49.14 & 6.77 & 6.44 \\
$1988-89$ & 26.22 & 6.87 & 17.40 & 3.96 & 48.67 & 3.81 & 4.81 \\
$1989-90$ & 25.83 & 3.03 & 17.59 & 5.72 & 48.62 & 4.48 & 4.59 \\
$1990-91$ & 25.68 & 4.96 & 17.71 & 6.25 & 48.45 & 5.21 & 5.57 \\
$1991-92$ & 26.11 & 9.50 & 17.76 & 8.05 & 48.02 & 6.76 & 7.71 \\
$1992-93$ & 24.18 & -5.29 & 18.30 & 5.35 & 49.13 & 4.63 & 2.27 \\
$1993-94$ & 24.34 & 5.23 & 18.46 & 5.48 & 48.97 & 4.20 & 4.54 \\
$1994-95$ & 24.65 & 6.57 & 18.17 & 3.60 & 48.77 & 4.80 & 5.24 \\
$1995-96$ & 25.79 & 11.72 & 17.84 & 4.80 & 47.96 & 4.99 & 6.76 \\
$1996-97$ & 25.33 & 0.12 & 17.73 & 1.29 & 48.75 & 3.61 & 1.93 \\
$1997-98$ & 25.95 & 4.52 & 17.10 & -1.61 & 48.57 & 1.68 & 2.03 \\
$1998-99$ & 25.40 & 1.95 & 17.08 & 4.07 & 48.95 & 4.99 & 4.18 \\
$1999-00$ & 25.93 & 6.09 & 16.69 & 1.53 & 49.06 & 4.15 & 3.91 \\
\hline
\end{tabular}

Source: 50 Years of Pakistan Volume I summary, Economic Survey, Various Issues.

Table 4. Export performance of clothing sector of Pakistan (Billion)

\begin{tabular}{cccc}
\hline Year & $\begin{array}{c}\text { Current Prices in US } \\
\text { Dollar }\end{array}$ & $\begin{array}{c}\text { Current Prices in } \\
\text { Rupee }\end{array}$ & $\begin{array}{c}\text { In 2000 Prices } \\
\text { (US Dollar) }\end{array}$ \\
\hline $1995-96$ & 1.33 & 45.02 & 1.10 \\
1996 & 1.40 & 54.74 & 1.24 \\
1997 & 1.42 & 61.41 & 1.23 \\
1998 & 1.38 & 69.25 & 1.29 \\
1999 & 1.65 & 85.43 & 1.50 \\
2000 & 1.72 & 100.76 & 1.72 \\
2001 & 1.70 & 104.39 & 1.65 \\
2002 & 2.22 & 129.76 & 2.00 \\
2003 & 2.42 & 139.35 & 2.06 \\
$2004-05$ & 2.71 & 160.84 & 2.21 \\
\hline
\end{tabular}

Source: All Pakistan Cotton Mills Association. 
Table 5. Pakistan's exports, imports and balance of trade (current prices) (US \$ Millions)

\begin{tabular}{cccccc}
\hline Years & Total Exports & Total Imports & $\begin{array}{c}\text { Balance of } \\
\text { Trade }\end{array}$ & $\begin{array}{c}\text { Exports as \% age } \\
\text { of Imports }\end{array}$ & $\begin{array}{c}\text { Trade Deficit } \\
\text { as \% age of GDP }\end{array}$ \\
\hline $1990-91$ & 6,131 & 7,616 & $-1,485$ & 80.5 & -3.1 \\
$1991-92$ & 6,904 & 9,252 & $-2,348$ & 74.6 & -4.3 \\
$1992-93$ & 6,813 & 9,941 & $-3,128$ & 68.5 & -5.3 \\
$1993-94$ & 6,803 & 8,564 & $-1,761$ & 79.4 & -2.8 \\
$1994-95$ & 8,137 & 10,394 & $-2,257$ & 78.3 & -3.6 \\
$1995-96$ & 8,707 & 11,805 & $-3,098$ & 73.8 & -4.2 \\
$1996-97$ & 8,320 & 11,894 & $-3,574$ & 70.0 & -4.6 \\
$1997-98$ & 8,628 & 10,118 & $-1,490$ & 85.3 & -2 \\
$1998-99$ & 7,779 & 9,432 & $-1,653$ & 82.5 & -2.2 \\
$1999-00$ & 8,569 & 10,309 & $-1,740$ & 83.1 & -2.4 \\
$2000-01$ & 9,202 & 10,729 & $-1,527$ & 85.8 & -2.1 \\
$2001-02$ & 9,135 & 10,340 & $-1,205$ & 88.3 & -1.7 \\
$2002-03$ & 11,160 & 12,220 & $-1,060$ & 91.3 & -1.5 \\
$2003-04$ & 12,313 & 15,592 & $-3,279$ & 79.0 & -3.9 \\
$2004-05$ & 14,391 & 20,596 & $-6,205$ & 69.9 & -6.3 \\
$2005-06$ & 16,469 & 28,581 & $-12,112$ & 57.6 & -11.1 \\
\hline
\end{tabular}

Source: Economic Survey of Pakistan (Various Issues).

It was December of 1973, when the LTA was replaced by new arrangement namely MFA (Multi Fibre Agreement). The MFA covered extensive variety of product like wool and synthetic fibres. MFA was re-negotiated in the GATT's Cotton committee after every few years. The basic goals of MFA were two fold (although they were not fulfilled accordingly), firstly to attain the progressive liberalisation of world's trade of Cotton products and secondly, smooth development of Cotton trade and to avoid interruption in individual markets/products. Accordingly encouraging the Cotton and clothing industries of developing countries were the core intend of the arrangements.

On the other hand, MFA basic regulations were not in line with the agreed ground rules of world trade under GATT. There were two basic differences between MFA and GATT; firstly, MFA was against the non-discrimination principle of GATT, by allowing developed countries to choose developing countries to restrict their exports, even as leaving mainly developed countries together. Secondly, MFA used the quantitative restrictions like quota to limit the exports of developing countries to developed countries while GATT was supposed to substitute quota with money equivalents like tariffs.

\subsection{Agreement on Cotton and Clothing under WTO}

In January 1995, Agreement on Cotton and Clothing (ATC) replaced the MFA, with the advent of the World Trade Organization (WTO). ATC set out a transitional process for the ultimate removal of quotas and the full adoption of Cotton and clothing products into GATT rules. It was signed in the Uruguay Round of negotiations by this agreement, countries Canada, the EU, Norway, and the US committed to a progressive elimination of MFA restrictions within 10 years, and since January 2005 the WTO is fully implemented.

During the Uruguay Round negotiations, the participants agreed that the sectors should progressively come under the non-discrimination rules of the GATT and end the special treatment of trade in Cotton and apparel. Therefore, the ATC was born with the objectives of fully incorporating Cotton and apparel into the WTO rules and disciplines, but in a gradual process would give importing countries in transition period to adjust their domestic sector to the new rules and avoiding sudden and costly disruption.

The process of liberalisation took place during January 1995-January 2005, with MFA-restricted goods returned to normal GATT rules in three phases. At the start of each phase of integration, importing countries integrated a 
specified minimum portion of their Cotton and apparel imports, based on total trade volume in 1990. The quota growth rate of products remaining under quota was also specified for each phase. In addition, import tariffs were being reduced under this agreement, on both Cotton and clothing, and on a wide range of other goods. See Table 6 for details.

Table 6. Evolution of ATC

\begin{tabular}{cccc}
\hline Date & $\begin{array}{c}\text { Minimum volume integrated } \\
\text { into GATT }\end{array}$ & $\begin{array}{c}\text { Accumulated volume } \\
\text { integrated into GATT }\end{array}$ & $\begin{array}{c}\text { Growth rate of } \\
\text { remaining quotas }\end{array}$ \\
\hline 1 Jan 1995 & $16 \%$ & $16 \%$ & $16 \%$ \\
1 Jan 1998 & $17 \%$ & $33 \%$ & $25 \%$ \\
1 Jan 2002 & $18 \%$ & $51 \%$ & $27 \%$ \\
1 Jan 2005 & $49 \%$ & $100 \%$ & Full integration \\
\hline
\end{tabular}

Source: Whalley (1997).

The first stage, called for the integration of products, began on January 1, 1995, comprising not less that 16 percent of the total volume of each member's 1990 imports of the products listed in the annex to the agreement. The second phase started at the beginning of 1998 with a specified minimum trade integration rate of 17 percent and an increase of the quota growth rate to 25 percent higher than the previous stage rate. The third phase began in 2002 and achieved the targets of 18 percent (integration rate) and 27 percent (quota growth rate). At the end of third stage, January 1, 2005, 49\% or all remained quotas on WTO members were eliminated.

A specific transition safeguard mechanism was also included in the agreement that could be applied at any stage to products which were not integrated into GATT. Action under the mechanism was suppose to be taken against individual exporting countries if they would demonstrate by an importing country that a sharp and substantial increase of imports from an individual country could cause serious damage or threaten its domestic industry (Nordas, 2004). This action was suppose to be taken by mutual agreement, following consultation, or unilaterally, but subject to review by the Cotton Monitoring Body (TMB).

It was a great accomplishment in trade negotiations to bring the MFA under GATT rules. Keeping in mind the distortions that had arisen from the MFA over a wide range of products and countries, it was expected that the impact of the changes would be strong. Now importing countries can benefit from lower import prices due to the abolishment of quota rents. They can source from the most efficient exporters, while resource allocation in importing countries is expected to improve as a result of import competition. Exporting countries may benefit or not, depending mainly on their comparative advantage.

\section{Conclusion}

The main objective of this research paper is to investigates the WTO implication on cotton trade in Pakistan. The competition was restricted due to quota system and it allowed less competitive exporters to export more than their competitive share. Now less competitive exporters are losing their market share. Exporting countries which were previously limited by the MFA are gaining from increased market access. However, exporting countries are facing lower prices as a result of increased competition, although production and exporting is rationalized, with a move to more efficient sectors.

\section{References}

All Pakistan Cotton Mills Association (APTMA). (2007). Retrieved from www.aptma.org.pk

Avisse, R., \& Fouquin, M. (2001). Cotton and Clothing the End of Discriminatory Protection. La Lettre du CEPII, No. 198.

Aziz, E., Hertel, T., \& Wolf, M. (2003). Estimating the Impact of WTO and Domestic Reforms on Indian Cotton and Cotton Sector: A General Equilibrium Approach. Review of Development Economics, 7(3), 343-359. http://dx.doi.org/10.1111/1467-9361.00195

Badar, H. (2002). Recipe for Cotton in WTO Regime. Published in the Daily Dawn, Islamabad, Pakistan.

Baig, M. I. (2002). Global Scenario of Cotton and Position of Pakistan. Published in the Daily Dawn, Islamabad, Pakistan. 
Baldwin, R. E. (2003). Openness and Growth: What's the Empirical Relationship?. National Bureau of Economic Research (NBER) Working Paper 9578. NBER: Cambridge.

Banuri, T. (1998). Cotton and Cotton in Pakistan. Prepared for United Nations Environment Programme.

Bari, K. M. (2003). The Competitive Advantage of Pakistan - Empirical Analysis of the Cotton/Apparel Industry, $\mathrm{PhD}$ Thesis. University of Strathclyde, Glasgow, U.K.

Bhagwati, J. (2004). In Defense of Globalization. New York: Oxford University Press.

Burki, A. A. (1999). Efficiency Wages in Pakistan's Small Scale Manufacturing. Lahore Journal of Economics, $4(1), 1-22$.

Diao, X., \& Somwaru, A. (2001). Impact of the MFA Phase-Out on the World Economy: An Intertemporal General Equilibrium Analysis. TMD Discussion Paper No. 79, Trade and Macroeconomics Division, International Food Policy Research Institute.

Dijk, W. O. (2002). The VOC's (Verenigde Oostindische Compagnie) Trade in Indian Cotton with Burma. Journal of Southeast Asian Studies, 33(3), 1634-1680. http://dx.doi.org/10.1017/S0022463402000358

Edwards, S. (2002). Review of Joseph E. Stiglitz's Globalisation and its Discontents. Retrieved from http://www.anderson.ucla.edu/faculty/sebastian.edwards/Stiglitz.pdf

Epstein, S. B. (2003). GATT: The UR Agreement and Developing Countries, Inter-American Trade Report. The National Law Centre for Inter-Americana Free Trade. Retrieved from www.natlaw/pubs/gatt.htm

Exporting to European Union Guide. (2006). Retrieved from http://www.cbi.nl/accessguide

Flanagan, M. (2003). Apparel Sourcing in the 21st Century, 10 Lessons So Far. Retrieved from www.juststyle.com

Francois, J., \& Spinanger, D. (2001). With Rags to Riches but Then What? Hong Kong's T\&C Industry vs. the ATC and China's Accession, Paper prepared on the Fourth Annual Conference on Global Economic Analysis, Purdue University, West Lafayette, Indiana, June 27-29, 2001.

Government of Pakistan and Japan International Co-operative Agency (JICA). (1991). Study on the Cotton Industry Development Programme in Islamic Republic of Pakistan, Islamabad, Pakistan.

Government of Pakistan. (2000). Cotton Vision 2005, Islamabad, Pakistan.

Government of Pakistan. (2001). Ministry of Commerce, Text of the Trade Policy of Pakistan, Islamabad, Pakistan.

Government of Pakistan. (2002). Ministry of Commerce, Text of the Trade Policy of Pakistan, Islamabad, Pakistan.

Government of Pakistan. (various years). Pakistan Statistical Year Book, Federal Bureau of Statistics (FBS), Statistics Division, Islamabad.

Government of India. (2003-04). Ministry of Finance, Economic Survey of India, Ministry of Finance, New Delhi.

Government of Pakistan. (various years). Economic Survey of Pakistan, Ministry of Finance, Islamabad.

Government of Pakistan. (2004). Information About Different Ministries. Retrieved from http://www.pakistan.gov.pk/ministries/NewsInfo.jsp?div=Cottonministry\&MinID=40\& file=0307064.xml\& path $=$ ministries/Cotton-ministry/

Hassan, P. (1998). Pakistan's Economy at the Crossroads: Past Policies and Present Imperative. Pakistan: Oxford University Press, Karachi.

Henley, J., \& Kirkpatrick, C. (2001). Industrial Development in a Changing Global Economy. In M. Huq and J. Love (eds), Strategies for Industrialisation: The Case of Bangladesh. Dhaka: University Press Ltd.

Husain, I. (1999). Pakistan the Economy of an Elitist State. Pakistan: Oxford University Press, Karachi.

Huq, M. M., \& Tribe, M. (2004). Economic Development in a Changing Globalised Economy. Journal of International Development, 16, 911-923. http://dx.doi.org/10.1002/jid.1160

Ianchovichina, E., \& Martin, W. (2001). Trade Liberalization in China's Accession to the World Trade Organization. World Bank, June 2001. 
Institut Francais De La Mode. (2005). Cotton and Clothing Liberalization - IMF and Partners, Study on the Implications of the 2005 Trade liberalization in the Cotton and Clothing Sector, Tender No ENTR, 02/04, Paris.

International Monetary Fund (IMF), Economic Forum. (2004). In Defense of Globalization. Retrieved from http://www.imf.org/external/mmedia/view.asp?eventID $=236$

International Trade Centre (ITC). (various issues). Retrieved from http://www.intracen.org

International Monetary Fund (IMF). (various issues). International Financial Statistics, Year Book. Washington D.C.: IMF. Retrieved from http://www.imf.org

Jeffery, S. (2002). What is Globalisation?. Published in the, Guardian Unlimited, (UK Daily Newspaper) Thursday October 31, 2002.

Jones, R. J. B. (1995). Globalization and Interdependence in the International Political Economy: Reality and Rhetoric, (London and New York).

Kathuria, S., \& Bhardwaj, A. (1998). Export Quota and Policy Constraints in the Indian Cotton and Garment Industries, World Bank, 1998.

Kathuria, S., Martin, W., \& Bhardwaj, A. (2001). Implications for South Asian Countries of Abolishing the Multifibre Arrangement, World Bank Working Paper 2721, Washington, D.C. Retrieved from www.worldbank.org

Kemal, A. R. (1978). An Analysis of Industrial Efficiency in Pakistan: 1959-60 to 1969-70, PhD thesis, University of Manchester, 1978.

Khan, S. R. (1999). Fifty Years of Pakistan Economy: Traditional Topic and Contemporary Concerns. Pakistan: Oxford University Press, Karachi.

Khan, Z. (2003). Impact of post-ATC environment on Pakistan's Cotton trade, UNDP-Asia Pacific Regional Initiative on Trade, Economic Governance, and Human Development.

Krugman, P. R., \& Obstfeld, M. (2006). International Economics; theory and policy (7th ed.). New York: Addison Wesley Longman Press.

Lankes, H. P. (2002). Market Access for Developing Countries. In Finance and Development, 39(3), September.

Makhdoomi, S. K. (2000). Price Competitiveness and Performance of Manufactured Exports: A Case Study of Pakistan 1970-98, PhD Thesis, University of Strathclyde, Glasgow, U.K.

Naeem, A. R. (1995). A Study of Pakistan's Trade and Economic Relations with the European Community in the Context of EC's Trade and Development Policies, PhD thesis, University of Glasgow, U.K.

Naeem, A. R. (2006). Trade Implications for Pakistan in the European Union Market in the Milieu of EU Enlargement from EU15 to EU25, Postdoctoral thesis, University of Glasgow, U.K.

Nordas, H. K. (2004). The Global Cotton and Clothing Post the Agreement on Cotton and Clothing, WTO Discussion Papers No. 5, Geneva 2004.

OECD. (2003). Liberalizing Trade in Cotton and Clothing, A Survey of Quantitative Studies.

Papanek, G. F. (1967). Pakistan's Development: Social Goals and Private Incentives, Cambridge, Massachusetts: Harvard University Press, 1967.

Quiros L. Bernaldo de, Cato Journal (2004). the review of, Why Globalisation Works, by Martin Wolf. Retrieved from http://www.cato.org/pubs/journal/cj24n3/cj24n3-13.pdf

Reich, S. (1998). What is Globalization? Four Possible Answers, working Paper \# 261.

Saeed, S. A. (1999). Economy of Pakistan, Lahore, New fine Printing Press.

Saeed, S. A. (2000). Economy of Pakistan, Lahore, New fine Printing Press.

Sheikh, H. R. (2005). Growth and BMR Requirements of the Cotton Industry - Problems and Prospects, Cotton Institute of Pakistan.

Silberston, Z. A. (1984). The Multi Fibre Agreement and the UK Economy, London, United Kingdom.

Soros, G. (2002). George Soros on Globalisation. New York: Public Affairs.

Stiglitz, J. E. (2002). Globalization and its Discontents. W.W. Norton \& Company, New York and Penguin Books, London, United Kingdom. 
Terra, M. I. (2001). Trade Liberalization in Latin American Countries and the Agreement on Cotton and Clothing in the WTO, Paper Presented at the Conference on the Impact of Trade Liberalization Agreement on Latin America and the Caribbean, Inter-American Development Bank, Washington D.C, Nov. 5-6, 2001.

The Complete Review's Review. (2007). Retrieved from http://www.complete-review.com/reviews/economic/wolfm.htm - basic

USITC. (2002). The Economic Effects of Significant U.S. Import Relations, Third Update, Pub. 3519, June 2002.

Wolf, M. (2004). Why Globalisation Works, Yale University Press London, United Kingdom.

Wolf, M., \& Winters, L.A. (1996). The Uruguay Round and Developing Countries, Cambridge University Press, Cambridge, pp.216-250.

World Trade Organisation. (various issues). International Trade Statistics. Retrieved from www.wto.org

World Trade Organization. (2001). Comprehensive Report of the Cotton Monitoring Body to the Council of Trade in Goods on the Implementation of the Agreement of Cotton and Clothing During the Second Stage of the Integration Process, G/L/459, 31. July 2001.

Yanikkaka, H. (2003). Trade Openness and Economic Growth, A Cross-country Empirical Investigation. Journal of Development Economics, 72(1), 57-89. http://dx.doi.org/10.1016/S0304-3878(03)00068-3

Zaidi, S. A. (1999). Issues in Pakistan's Economy, Oxford University Press, Karachi, Pakistan. 